Review on Agriculture and Rural Development 2017 vol. 6 (1-2) ISSN 2063-4803

\title{
SOME EFFECTS OF NATIONWIDE SMALL RUMINANT BREEDING PROJECT UNDER THE BREEDER CONDITIONS ON GOAT FLOCKS AND THEIR OWNER
}

\author{
Mustafa SaAtci ${ }^{1}$, ÖZKan Elmaz ${ }^{1}$, Aykut Asim AKbaş ${ }^{1}$, ÖZgecan Korkmaz \\ AĞAOĞLU ${ }^{1}$, MehMet SARI ${ }^{1}$, MAHIYe ÖZÇElik Metin ${ }^{1}$ \\ ${ }^{1}$ Mehmet Akif Ersoy University, Veterinary Faculty, Department of Animal Science, \\ 15030, Istiklal Campus, Burdur, TURKEY
}

\begin{abstract}
The nationwide small ruminant breeding project under the breeder condition has been started in the year of 2005. The project planned to solve some of the problems related with small ruminant breeding system. Especially, to find the solution for inadequate productivity, lack of organisation, insufficient collaborations, low education, and unreliable registration system were the main parts of the mentioned project. Project planned with sub-projects according to districts and breeds. At the beginning, project started with sheep flocks, and then goats were included. Local sheep and goats associations were involved the project. Project personals were chosen and educated according to project rules. Also, meetings were organised with the selected breeders and the breeders were informed about the projects and their duties. In our region we were examined the goat flocks from the year of 2011 to at the end of 2016. During the period of the project some increases on the live weights of the animals have been detected. Also, breeders directly or indirectly had education about their job. At the end of the scheme, some of the positive effects of the project have been observed on the lives of breeders, goats, collaborations and market situations.
\end{abstract}

Keywords: Turkey, breeder condition, goat, nationwide project

\section{INTRODUCTION}

Small ruminant and their various products are important for both developing and developed countries. Generally small ruminants reflect the characteristics and the culture of a population or vice-verse. The importance of small ruminants breeding system and their positive effects on the social life, economic level and well-being condition of people in developing countries has been mentioned by researchers (BOYAZOGLU ET AL., 2005, KosGey ET AL., 2008, KOSGEY, 2004). Small ruminants are also important for the utilisation of the lands where other farm animals cannot. Additionally, regions where crop production is impractical can easily be use by small ruminant as food resources (BAKER AND REGE, 1994). Therefore, improvement local, regional, and nationwide programmes are necessary to increase and sustain the productivity of small ruminants. Constant improvement is related with genetic progress and genetic improvement programmes for sheep and goats will only be successful when accompanied by a good understanding of the different farming systems and when simultaneously addressing several constraints such as feeding, health control, general management, and cost and availability of credit and marketing infrastructure (KOSGEY ET AL., 2008, BAKER AND GRAY, 2004).

As a farm animal, goat has special qualifications in terms of breeding, production, cultural addition and social perception. Moreover, keeping goat is linked with socioeconomic and recreational requirements of the country people (DEVENDRA, 1998, KIVRAK, 2014). Goat rearing in Turkey is one of the hardest rearing systems. This system is conducted in harsh environment and whole family of the breeders involve this activity, as can be seen in the life of nomadic goat breeders. This explained livestock practice is still active with almost all structures in West Mediterranean part of Turkey. 
All the applied projects on the small ruminant population in the rural area more or less affect their owners in terms of various factors. Similarly, nationwide small ruminant breeding project under the breeder conditions affected both goats and their keepers. These effects can be measured on the traits of goats and the life style of the keepers.

This study aimed to detect and illustrate all the defined changes for both goats and breeders using the data and situations before and after the mentioned project.

\section{MATERIAL AND METHOD}

Effects of the nationwide small ruminant breeding project under the breeder conditions were investigated in West Mediterranean region of Turkey. Investigation was carried out in the cities of Antalya, Burdur and Muğla. Generally, areas on the Taurus Mountains were included the study. Local Hair and Honaml goats and their owners were evaluated. Studied area is the best place to see the entire characteristics of extensive goat rearing system. The flocks for the project have been selected according to breed characters and the rules of the project. In addition, project personal have been educated with successive seminars according to project objectives. Also, breeders have been gathered several times to explain the details of project. The best $10 \%$ of male kids and $20 \%$ of female kids have been selected from each member flock according to 90 days performance. Those animals were not allowed to be sold and kept in the flock as breeding animals for next generation. Performances of goats were measured beginning and at the end of the project. All the measurements have been illustrated in the Tables as digital data. Changes in the lives of the breeders were also defined with comparative observations. Some dramatic changes were observed and documented with the onsite pictures.

\section{RESULTS}

Collected and formed performance data before and after the project have been showed in the Tables 1 and 2.

Table 1. Changes in the birth weights and $90^{\text {th }}$ day live weights

\begin{tabular}{|l|c|c|c|c|}
\hline & & Birth Weight & & $90^{\text {th }}$ Day Weight \\
\hline & & Mean \pm SEmean & & Mean \pm SEmean \\
\hline Hair Goat & $\mathrm{n}$ & & & \\
\hline 2012 & 8989 & $3.25 \pm 0.01$ & 8185 & $15.40 \pm 0.06$ \\
\hline 2016 & 14342 & $3.24 \pm 0.01$ & 13722 & $16.74 \pm 0.06$ \\
\hline Honaml1 Goat & $\mathrm{n}$ & & $\mathrm{n}$ & \\
\hline 2012 & 8425 & $3.49 \pm 0.01$ & 7457 & $17.50 \pm 0.06$ \\
\hline 2016 & 10370 & $3.46 \pm 0.01$ & 9842 & $18.91 \pm 0.06$ \\
\hline
\end{tabular}


Review on Agriculture and Rural Development 2017 vol. 6 (1-2) ISSN 2063-4803

Table 2. Changes in reproduction traits

\begin{tabular}{|l|c|c|c|c|c|c|c|}
\hline & $\begin{array}{c}\text { Number of } \\
\text { kidding } \\
\text { does }\end{array}$ & $\begin{array}{c}\text { Number of } \\
\text { single kidding } \\
\text { does }\end{array}$ & $\begin{array}{c}\text { Single } \\
\text { birth rate } \\
(\%)\end{array}$ & $\begin{array}{c}\text { Number of } \\
\text { twin } \\
\text { kidding } \\
\text { does }\end{array}$ & $\begin{array}{c}\text { Twin } \\
\text { birth rate } \\
(\%)\end{array}$ & $\begin{array}{c}\text { Number } \\
\text { of kids }\end{array}$ & $\begin{array}{l}\text { Litter } \\
\text { size }\end{array}$ \\
\hline Hair Goat & & & & & & & \\
\hline 2012 & 8555 & 8120 & 95.0 & 435 & 5.0 & 8990 & 1.05 \\
\hline 2016 & 8910 & 8059 & 90.4 & 851 & 9.6 & 9761 & 1.10 \\
\hline $\begin{array}{l}\text { Honaml1 } \\
\text { Goat }\end{array}$ & & & & & & & \\
\hline 2012 & 7551 & 6677 & 88.4 & 874 & 11.6 & 8425 & 1.12 \\
\hline 2016 & 9130 & 7892 & 86.4 & 1239 & 13.6 & 11680 & 1.27 \\
\hline
\end{tabular}

Investigated production and reproduction traits showed a modest increase from the beginning of the project to the end of it. This project was also an indirect education method for the breeders, because most of them applied some new techniques to their flocks. These methods were discussed in detail in the following section.

Changes in the life style of the breeders and the conditions of the barns have been observed clearly and demonstrated with on-site taken pictures.
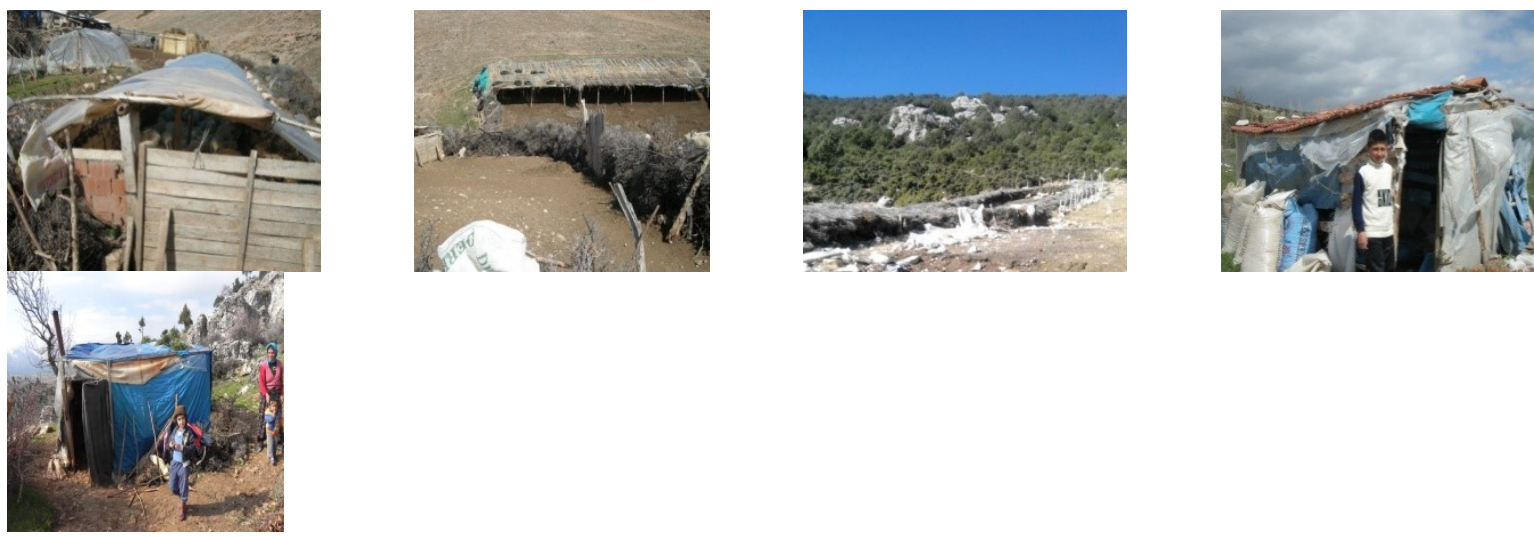

Figure 1. Before the project
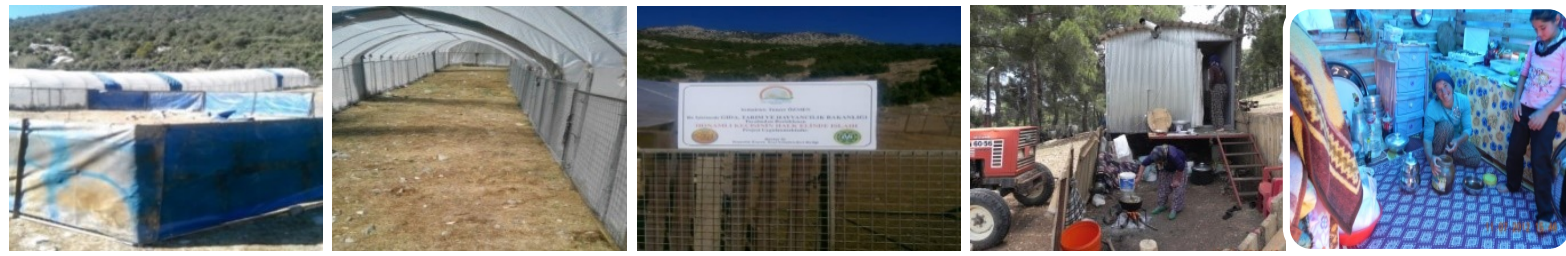

Figure2. After the project

\section{CONCLUSIONS}

Modest increase in production and reproduction traits has been observed in the last year of the project according to previous years. The effects of the applications have been clearly observed in the last year. Selecting the best bucks and best does and culling the weak animals according to kept record, learning how to keep the pedigree and performance records and avoid form inbreeding might cause these increases. With these defined increases, breeders understood the effectiveness of the applied techniques in the project. 
Goat rearing in the region is applied according to traditional methods (BOYAZOGLU ET AL., 2005) therefore to teach new techniques to the breeders were not easy. Also, breeders have not easily accepted the implications. When they have seen an objective increase and got benefit from these increases, their intention has become clear to keep up with the project. This situation can be used for the new applications on the small ruminant holders with an important criterium that "In order to make the breeders believe for the results of new applications, the best way is to show them the objective results."

It is a reality that most of the extensive small ruminant breeders' education level is low (BUDAK ET AL., 2005, CAN, 2014). Therefore, applications related to recording system are weak in this society. The project was successful to teach them record keeping and make them continue this application. They also realized the importance and the differences of pedigree and performance records. This achievement might be accepted as education part of the project.

Goat breeders cannot live an intense social life (DEVENDRA, 1998, KIVRAK, 2014). Project gave an opportunity to the breeders to make communication with other breeders and all the partners of the project and the sector. Workshops, fairs, meetings and contests were great opportunity for this kind of relationships. At the end of the project, a valuable understanding among the project partners has been established. This establishment can easily be used to define and to solve the certain problems of the sector.

With this project, the State showed a valuable interest to the small ruminant breeders. This interest is priceless for the breeders, because for a long time they used to think that they are a forgotten child of the State. The interest of State made their confidence durable and their hope alive for the future of this business.

At the end of the project the region and whole Turkey have a bunch of educated small ruminant breeders who are ready for teamwork and scientific collaboration. Breeders understood the importance of recording and its usage in the flocks. Each of the breeders became a member of an association or breeding society. Also, official body got valuable experience to do similar works on the rural area.

Project has significantly affected the life style of the breeders. It has also changed the performance of goats, the houses of breeders, the barns of animals and the perceptions of the breeders. The project has created awareness for both, the State and breeders in term of small ruminant sector.

\section{REFERENCES}

BAKER, R.L., GRAY, G.D. (2004): Appropriate breeds and breeding schemes for sheep and goats in the tropics. In: Sani, R.A., Gray, G.D., Baker, R.L. (Eds.), Worm Control for Small Ruminants in Tropical Asia, Monograph, No. 113. Australian Centre for International Agricultural Research (ACIAR), pp. 63-95.

BAKER, R.L., REGE, J.E.O. (1994): Genetic resistance to diseases and other stresses in improvement of ruminant livestock in the tropics. In: Proceedings of the Fifth World Congress on Genetics Applied to Livestock Production, vol. 20, University of Guelph, Canada, August 7-12, 1994, pp. 405-412.

Boyazoglu, J., Hatziminaoglou, I., Morand-Fehr, P. (2005): The role of the goat in society: Past, present and perspectives for the future. Small Rumi Res. 60: 13-23.

BUDAK, D.B., DARCAN, N., KANTAR, M. (2005): Women farmers and extension services in small ruminant production in mountain areas of Turkey. J. of Arid Environments 62: 507515. 
CAN, M. F. (2014): A socio-economic analysis of small ruminant breeders' membership relations and organizational effectiveness. Ankara Üniv Vet Fak Derg 61: 119-124.

DEVENDRA, C. (1998): Improvement of small ruminant production systems in rainfed agroecological zones of Asia. Ann. of Arid Zone 37: 215-232.

KIVRAK, R. (2014): Yürüyen Türkler yörükler. Ege reklam basım sanatları San. Tic. Ltd.Şti. İzmir

Kosgey, I.S., Rowlands, G.J, Van Arendonk, J.A.M., BAKer, R.L. (2008): Small ruminant production in smallholder and pastoral/extensive farming systems in Kenya. Small Ruminant Research 77: 11-24.

KosGeY, I.S. (2004): Breeding Objectives and Breeding Strategies for Small Ruminants in the Tropics. Ph.D. Thesis. Wageningen University, The Netherlands, 272 p. 